\title{
Digital Technologies for the Assessment of Cognition: A Clinical Review
}

Amy Chinner ${ }^{1}$, Jasmine Blane ${ }^{1}$, Claire Lancaster ${ }^{2}$, Christopher Hinds², Ivan Koychev ${ }^{1}$

Affiliations: ${ }^{1}$ Department of Psychiatry, University of Oxford, Warneford Hospital, Oxford, UK;

${ }^{2}$ Big Data Institute, University of Oxford, Old Road Campus, Oxford, UK

Corresponding author: Ivan Koychev, Department of Psychiatry, University of Oxford, Warneford Hospital, Oxford, OX37JX, UK; ivan.koychev@psych.ox.ac.uk

\section{Abstract:}

Dementia is the most widespread neurodegenerative disorder globally, and is associated with an immense societal and personal cost. With dementia prevalence projected to triple worldwide by 2050 , there is an urgent need to increase the efficacy of dementia prevention, treatment and care. Rapid advancements in digital technology is starting to provide new opportunities to alleviate some of the challenges faced by dementia clinicians and researchers. This clinical review aims to summarise the current evidence for the use of pervasive digital technologies to monitor and support cognition in pre-clinical, prodromal and demented populations. Generally, the digital technologies provided valid measures of users' cognitive function. However, most of the systems are still in the initial development stages, with limited data on acceptability in patients. Although the use of digital technology to monitor and support cognitive domains affected by dementia is a promising area of development, additional research validating the efficacy, utility and cost-effectiveness of these systems in patient populations is needed. 


\section{Introduction:}

In 2015, Alzheimer's Disease International reported that an estimated 46.8 million people were living with dementia worldwide, with an associated cost of US\$818 billion ${ }^{1}$. With the percentage of the world population aged over-60 predicted to double by $2050^{1}$, the societal, economic and personal burden of this "dementia epidemic" ${ }^{2}$ is a major concern for the sustainability of healthcare ${ }^{3}$. It has been argued that addressing preventable risk factors for dementia, such as sedentary lifestyle and poor diet, could reduce the disease burden ${ }^{3}$. To achieve this, we must understand which risk factors to target, and whether a critical intervention period exists.

Omnipresent digital technologies, such as smartwatches and smartphones, could help address these two issues, through their ability to obtain a wealth of ecologically valid, longitudinal information on health, behaviour and cognitive function. This rich feedback provides new opportunities to identify potentially modifiable risk factors, detect early changes in behaviour indicative of disease and track disease trajectories over time ${ }^{4}$.

As well as monitoring health and cognition, digital technologies that provide adaptive assistance are now emerging due to advances in machine learning. The application of domotics - the integration of technology into residential structures ${ }^{5}$ - to dementia care has resulted in the development of adaptive "smart homes" to assist patients with Activities of Daily Living (ADLs) affected by their cognitive deficits ${ }^{6}$. With the majority of dementia care costs falling on unpaid carers and long-term institutional social care ${ }^{7}$, technological developments promoting patient independence and quality of life, will be crucial to reducing the growing burden of neurodegenerative diseases.

Beyond providing assistance, digital technology is being explored as a potential method of nonpharmacological intervention. Cognitive training smartphone applications, which aim to strengthen various cognitive domains ${ }^{8}$ (defined by the National Institute of Health as Attention, Perception, Declarative Memory, Language, Cognitive Control and Working Memory ${ }^{9}$ ), are particularly prevalent. There is already evidence that 'structured programs of cognitively demanding computer tasks' can 
be beneficial for healthy brain ageing ${ }^{10}$. The adaption of these programs into downloadable smartphone applications addresses several former limitations including: integration into daily life, implementation burden, and distribution scope ${ }^{11}$.

This review aimed to provide a summary of current developments in digital technologies for cognitive monitoring, assistance and training in elderly demented, prodromal and pre-clinical populations. We focused our search on three technologies based on their immediate relevance to cognition, dementia and healthcare: mobile (smartphone and tablet) applications, wearable technology and smart home systems.

\section{Methods}

We searched PubMed, Science Direct and Google Scholar records (last search 25/10/2017) using the terms: 'mobile technology' or 'wearable technology' or 'smartphone' or 'smartwatch' or 'smarthome' or 'domotics' and 'dementia' or 'cognition' or 'elderly' or 'Alzheimer's' or 'health'. Articles in English were screened, and studies selected that evaluated digital technologies to monitor or assist cognitive function in older adults. We included technologies that deduced cognitive function through ADL performance. Articles piloting relevant technology in younger adults were also included when intent to apply the technology to older populations at risk of, or living with, dementia was demonstrated. Additional studies, referenced by articles identified in the original search, were also included. Due to the heterogeneity of digital technology and outcomes reviewed, a comprehensive systematic review was beyond the scope of this paper.

\section{Presentation}

Our review identified 24 articles detailing digital technologies with capacity to analyse cognitive function in older adults at various stages of a dementing disease; see the technology index (Table 1). 


\section{Mobile applications}

Seven identified articles presented cognitive-focused smartphone/tablet apps. The apps' objectives could be generally divided into three categories: cognitive monitoring, assistance and training.

\section{Cognitive Monitoring:}

Three applications were designed to monitor cognitive function in older adults. iVitality ${ }^{12}$ and ColorShape Test $(\mathrm{CST})^{13}$ aim to provide reliable means to assess cognition in 'at-risk' populations for dementia; DelApp ${ }^{14}$ focuses on identifying delirium in hospital inpatients.

iVitality employs five digitally adapted versions of standard cognitive tests (Stroop, Reaction Time, Trail Making, N-Back and Memory-Word tests) ${ }^{12}$. The tasks were piloted on 151 individuals with familial risk of dementia (mean age 57) over six months ${ }^{12}$, with moderate correlation for digital Trail Making and Stroop against their lab-based counterparts (correlation coefficients range 0.4-0.6) and adherence ranging from $48 \%$ to $67 \%$. The developers concluded that smartphone-based cognitive testing is feasible in cognitively normal individuals aged 50+ years, with acceptable levels of correlation with gold standard, lab-based testing ${ }^{12}$.

CST is a smartphone-optimised webpage developed to measure cognitive processing speed in the elderly ${ }^{13}$, through participants' learning and recalling shape colours. In a feasibility study of 57 cognitively healthy older adults CST performance correlated with performance on standard measures of global cognition (MMSE), processing speed and attention (Digit Span and Trail Making tests), but not tests of executive function (verbal fluency) or episodic memory (Logical Memory Test $)^{13}$. As only 18 participants had prior possession of a smartphone, the author's concluded the task's usability in older adults was not dictated by smartphone familiarity.

DelApp is a computerised version of the Edinburgh Delirium Test Box (EDTB); an assessment of visual sustained attention in general hospital inpatients ${ }^{14}$. No statistical difference was found between performance on the DelApp and the standard EDTB in 20 elderly cognitively healthy inpatients. DelApp also reliably differentiated patients with delirium from dementia patients (despite 
comparable cognitive performances) and from those with no cognitive impairment in 156 elderly inpatients (AUC $=0.96$ with $98 \%$ sensitivity and $93 \%$ specificity $)^{14}$. The conclusion was that DelApp provides an accessible and reliable means of monitoring delirium emergence in inpatient populations.

Cognitive Assistance:

Technology Adoption and Usage Tool (TAUT) ${ }^{15}$, was designed to provide cognitive assistance for individuals with episodic memory deficits through an adaptive ADL reminder system. By assimilating information from user inputs and context-aware sensors, the app adapts reminder delivery to improve integration with the user's lifestyle over time. TAUT is currently is being tested in an elderly, cognitively impaired population ${ }^{16}$, following a pilot in healthy younger adults where $73 \%$ of reminders were acknowledged within 12.38 seconds $^{15}$.

\section{Cognitive Training:}

Four apps were designed as primary and secondary dementia prevention methods with varied cognitive targets. Two apps, SMART and Fit Brains ${ }^{17}$, utilise multi-domain programmes of gamified cognitive tasks to improve cognitive reserve in preclinical older adults. SMART specifically targeted attention and memory (working and declarative), while Fit Brains generally covered most of the NIH cognitive domains ${ }^{17}$. In a randomised control trial, the efficacy of the apps for improving working and declarative memory in 53 older adults (mean age 59 years) with subjective memory complaints was investigated comparatively over 8 weeks ${ }^{17}$. Statistically significant improvements in overall and auditory-verbal working memory scores on the Memory Diagnostic System (MDS, a computerized neuropsychological battery ${ }^{18}$ ) were demonstrated for SMART, but not Fit Brains. The authors concluded that the greater focus of the SMART programme's tasks led to the working memory improvements on the MDS. However, this did not translate to participants' self-reported memory contentment, which only improved post-test in the Fit Brains group ${ }^{17}$. 
Two additional cognitive training apps are currently in design. The modified Attention Training Application (ATA) ${ }^{19}$ implements an adaptive working memory and attention (dual-n-back) task over two weeks to reduce executive deficits in people with mild cognitive impairment (MCl). The task was piloted on twelve $\mathrm{MCl}$ patients and healthy older adults (mean age 79 years), who on average rated the ATA as $60 \%$ interesting and $72.5 \%$ easy to use ${ }^{19}$. Suggested modifications are being implemented for future feasibility testing.

Healthebrain ${ }^{8}$ employs a three week Square-Stepping Exercise (SSE) to improve visuospatial memory in preclinical and $\mathrm{MCl}$ older adults. The user learns and reproduces patterns displayed on a smartphone screen by walking, holding the device parallel to the floor ${ }^{8}$. Non-computerised SSE has been observed to improve global cognitive functioning, especially attention and cognitive control, in older adults ${ }^{20}$. On piloting the app with 19 healthy or $\mathrm{MCl}$ older adults (mean age 68 years), 60\% of the participants reported the app easy to use, or comparable to the lab-based SSE task ${ }^{8}$. Future work is needed to establish the validity of an app-based SSE program as a cognitive intervention.

\section{Wearables}

Ten studies identified reported wearable technologies (smartwatches, accelerometers, cameras and glasses) for elderly preclinical and demented populations, with objectives that could be divided into cognitive monitoring and assistance.

\section{Cognitive Monitoring:}

Smartwatches: Four articles presented smartwatches that assess physical and, by proxy cognitive, function in dementia patients. WanderRep ${ }^{21}$, is a smartwatch-based reporting tool for caregivers of wandering persons with dementia. The smartwatches' ability to record time, location, temperature and activity level is used to create a personalised profile of wandering risk. By modelling patient behaviour, irregular and dangerous wandering can be detected, and caregivers alerted ${ }^{21}$. The authors piloted the smartwatch with one care home based dementia patient, and five professional 
caregivers who determined potentially dangerous wandering events. The system reported high sensitivity and specificity to detect dangerous events (78\% and $89 \%$ respectively) and thus supporting their use in supporting independent living ${ }^{21}$.

Three identified systems $\left(\mathrm{Max}^{22}, \mathrm{u}\right.$-Healthcare ${ }^{23}$, Basis $\left.\mathrm{B} 1^{24}\right)$ use smartwatch-derived measures to create activity profiles of dementia patients. Both Max and u-Healthcare rely on location and step data to infer activity; Max employs a Bluetooth sensor system to obtain room-specific data, while uHealthcare utilises GPS, accelerometer and ambient light sensors to profile physical activity inside and outside the home. Max was piloted in the homes of thirteen healthy controls from the Dementia Care Ecosystem ${ }^{25}$ over 39 months ${ }^{22}$. Reported room detection accuracy was $91 \%$, and distinct user behaviour patterns could be detected. $u$-Healthcare was trialled in 8 participants with average step detection accuracy of $94.7 \%$ reported $^{23}$.

Basis B1 monitors dementia patients' activities using broader biological measures (optical blood flow, body temperature and galvanic skin response) captured by a smartwatch, combined with medical history ${ }^{24}$. It was piloted with one dementia patient alongside their existing home-based care and was reported not to cause discomfort or anxiety, and provided the caregiver with new information on the patient's night disturbances, sleep and physical activity ${ }^{24}$. There results suggest that smartwatch monitoring systems could be complementary tools for existing care practices by monitoring cognitive health and behaviour when caregivers are unavailable, and patient self-report is unreliable ${ }^{24}$.

Smartwatch technology has also been developed for preclinical populations. The Wrist Wearable Unit (WWU $)^{26}$ monitors home-based physical activity levels of preclinical older adults longitudinally using measures of step count, acceleration, and heart rate. Routine user activity, and subsequent deviations, are reported to healthcare professionals via an online platform. WWU was piloted in groups of two to twenty healthy adults ${ }^{26}$. WWU-derived activity levels correlated well with users' subjectively reported activity, WWU-calculated heart rate fell within $\pm 4 \mathrm{bpm}$ of pulse oximeter 
measures, and device worn/unworn status was correctly identified to one minute accuracy ${ }^{26}$. The authors concluded that WWU could help to reliably determine preclinical function, from which changes indicative of physical and cognitive decline could be ascertained.

Accelerometers: Accelerometers, portable electro-mechanical sensors, offer a more established and lower cost activity monitor than smartwatches. One study used accelerometer data to monitor older adults' physical activity, intending to infer cognitive status ${ }^{27}$. A waist-worn triaxial-accelerometer was used by 274 community-dwelling older adults over 22 months. Light physical activity (measured by the accelerometer and defined using established cut-offs ${ }^{28}$ ) was independently associated with lower scores (i.e. better cognitive function) on the AD8 - an eight-item informant interview probing memory, orientation, judgment, and $A D L s^{29}$ at follow-up ${ }^{27}$. The study suggested that promotion of higher levels of objectively measured light physical activity could help protect cognitive function in older adults.

Wearable Cameras: One study utilised a custom-made wearable camera system, worn by caregivers, to monitor patients' dementia-related behaviour ${ }^{30}$. The system was piloted with 18 dementia patients and their caregivers over two, seven-day periods or for one three to five day period. 341 hours of usable video was collected, containing 248 salient events (dementia-related behaviour or caregiving interaction $\left.\mathrm{s}^{30}\right)$. Further development may lead to this technology being used to provide validation of caregiver observations, and provide accessible, unbiased monitoring of changes in patients' behaviour, cognition and needs over time ${ }^{30}$.

\section{Cognitive Assistance}

Smartwatch: One study investigated commercially available smartwatch technology to provide ADL assistance for dementia patients ${ }^{31}$; implementing smartwatch apps, and a paired smartphone, to assist scheduling, navigation, orientation to time and communication, as well as monitor activity levels. The system was tested by five memory clinic patients and their spouses in a controlled lab setting. Initial feedback suggested only the scheduling, orientation and communication functions 
were usable $(90-100 \%$ success rate completing tasks using these functionalities, compared to $0 \%$ on the navigation and emergency help tasks) ${ }^{31}$. Results from a follow-up home pilot are pending.

Wearable Camera: SenseCam ${ }^{32}$ is a wearable camera system supporting autobiographical memory consolidation and retrieval in cognitively impaired people. SenseCam captures pictures every 30 seconds, or in response to specific triggers e.g. movement, which the patient subsequently reviews ${ }^{32}$. During a two week testing phase, the $\mathrm{MCl}$ patients' proportion of events correctly recalled increased significantly from $38 \%$ at baseline (no review) to $68 \%$ at day 13 ; while a diary review method showed no significant change in the patient's recall at day thirteen $(30 \%)^{32}$. This recall difference for events reviewed using SenseCam, a diary or no review was sustained at six months' follow-up. The patient also reported an increase in self-esteem and confidence.

Smart Glasses: One article presented a head mounted display system to assist mild-to-moderate dementia patients with navigation inside and outside the home ${ }^{33}$; consisting of a pair of smart glasses implanted LED lights and various sensors (including accelerometers and a GPS tracker), which communicate with a remote android unit via a Bluetooth headset. Caregivers can use the remote unit to monitor the patient's location and send navigational cues through the glasses LED's. Acceptability of visual navigational cues was demonstrated in feasibility testing in a group of dementia patients, with cue usability significantly influenced by LED positioning and dementia severity ${ }^{33}$.

\section{Smart homes}

Extensive research exists into applying smart home technology to dementia populations, focusing on providing daily assistance. While not designed to directly monitor cognition, by observing changes in patients' ADLs, we here report seven smart home systems which have potential to infer and monitor cognitive function. 


\section{Cognitive Monitoring:}

Smart home monitoring and assistance typically uses a 3-stage iterative process. Technologies in the infrastructure of the building - for example magnetic contact sensors, passive infrared motion sensors, and pressure mats ${ }^{34}$ - monitor the environment. Machine learning principles then conceptualise the data into patterns of behaviour, and subsequent deviations ${ }^{35} 36$. Finally, a decisionmaker system reacts to behavioural deviations and provides real time feedback to patients' and caregivers ${ }^{34}$. One study found acceptance of smart home monitoring and alert technology by patients and their families was predicated on perceived enhancements to the safety, and independence, of the patient, and to delay institutionalisation. ${ }^{37}$

Three identified studies assessed the accuracy of smart homes to determine participant's performance while completing ADL. The M2M/IoT platform smart home showed ADL detection accuracy to be $80-100 \%$ for most activities, including wandering detection and forgetting to take a shower ${ }^{38}$. The DemaWare2 system reported an average of $82 \%$ precision for recognising activities performed in a lab environment and $75 \%$ for activities performed in a residential smart home ${ }^{35}$. The third, found a significant correlation ( $r=0.54$ ) between the scores of ADL performance assigned by clinicians observing patient behaviour, and the performance scores assigned by the smart home ${ }^{36}$. However, for all, the smart homes accuracy for determining the user's performances varied depending on the type of activity being assessed; all three studies found smart home predictions of watching television, including remembering to turn off the TV, were less accurate than other ADLs. One explanation given was that quicker activities, involving fewer sensor interactions, were harder for the smart home to accurately identify, so subsequent deviations were less likely to be detected ${ }^{36}$. Sensor type may also make a difference e.g. detection of "forgetting to turn off the TV" was reliant on the sound exceeding the sensors threshold ${ }^{38}$.

A collection of studies from one Lab has assessed whether by monitoring a number of ADL, a smart home could detect cognitive function and decline. The ORCATECH group collected continuous, daily 
data from 480 homes since 2007, using an unobtrusive activity monitoring smart home (comprising motion, contact and pressure sensors, computer and phone monitoring, medication trackers and wireless scales) ${ }^{39}$. One study reported no differences in daily recorded computer activity (based on mouse movements) at baseline between groups of cognitively healthy compared to $\mathrm{MCl}$ participants; however, at follow-up two and three years later, a significant decrease in number of days with computer use, mean daily use and an increase in day-to-day variability was found in the $\mathrm{MCl}$ group compared to the cognitively healthy participants ${ }^{40}$. The authors concluded that computer usage is likely to be sensitive to cognitive change due to its reliance on multiple cognitive domains. The same investigators monitored medication adherence using a device with sensors built into the medication box signalling open and close events, demonstrating that the participants who performed worse on the Alzheimer's Disease Assessment Scale Cognitive Subtest (ADAS-cog) had significantly poorer medication adherence than the better performing group ${ }^{41}$.

The capability of two smart home systems to discriminate cognitive states and dementia status has also been examined. DemaWare2 system ${ }^{35}$ monitored data from 27 Alzheimer's disease, $38 \mathrm{MCl}$ and 33 cognitively healthy participants as they performed ADLs in a lab-based smart home. For the ADLs "making a phone call" and "paying a bank bill remotely", the system could distinguish between the three participant groups with up to $84 \%$ accuracy ${ }^{35}$. Similarly, the second study evaluated the ability of a machine learning method to classify the cognitive health status of 263 participants (196 cognitively healthy, $51 \mathrm{MCl}$ and 16 dementia patients) from $8 \mathrm{ADL}$ performed in a lab-based smart home ${ }^{36}$. Reasonable accuracy in differentiating between cognitively healthy and dementia participants was reported when combining data from all 8 ADLs, and on some individual ADL (sweeping, cooking and dressing), but not for differentiating between cognitively healthy and $\mathrm{MCl}$. By including only ADLs that demonstrated good prediction accuracy in isolation, the classification performance of the combinatorial model was improved ${ }^{36}$. These studies demonstrate that, while still in pilot stages, monitoring ADL performance by smart homes is feasible and can identify cognitive decline over time and infer cognitive states and dementia status. 


\section{Discussion}

Through this review we attempted to highlight the breadth of digital technology currently available for the assessment of cognitive function in elderly demented and pre-clinical populations. We identified technologies that allow direct monitoring of cognition (e.g. smartphone app) and those that monitor broader indices of activity and function that could deduce cognitive ability. This is a rapidly developing area, with the number of dementia-focused digital technologies doubling approximately every five years ${ }^{4}$. The timely adoption of such technology in clinical practice is a challenge that requires effective communication between developers and clinicians about the availability of such solutions ${ }^{4}$. Overcoming this barrier could provide some of the most promising opportunities to reduce the burden of dementia.

The main value currently available digital technology can offer, in terms of cognitive monitoring, is the capacity to provide more ecologically-valid, high-granularity data. This type of data could be crucial in the development of much needed pharmacological dementia treatments. Despite considerable investment, no disease modifying treatments are currently available, with several highprofile failures ${ }^{3}$, which may have been due to testing compounds too late in the disease process. Longitudinal, high-frequency measurements by digital technologies could detect subtle cognitive changes at-risk populations, allowing targeted interventions early in the illness.

Longitudinal monitoring of behaviour and physical health could also be of immediate benefit clinically. Systems providing information on potentially fluctuating neuro-behavioural symptoms, not displayed at clinic visits, may assist clinicians making earlier diagnoses from fewer visits. This could therefore reduce the time and cost burden for both clinicians and patients. Similarly, technological monitoring will enable clinicians to objectively track behavioural and cognitive changes more closely over time ${ }^{34}$, reducing the need to rely on subjective accounts. Finally, such systems can provide feedback directly to at-risk participants allowing for behavioural interventions where modifiable risk factors are concerned. 
For existing dementia patients, the development of increasingly adaptive, assistive systems can help preserve independence levels and quality of life for as long as possible ${ }^{42}$. Maintaining independence is a crucial goal for the sustainability of dementia care, as current population prediction show caregiver-to-patient ratio is expected to reduce dramatically by $2050^{4}$. Furthermore, the trend of adults moving away from cities into rural areas post retirement poses a significant challenge to healthcare delivery. Therefore the development of systems that provide support and prevent emergency situations $\mathrm{s}^{24}{ }^{34}$ when carers are unavailable, or allow carers to remotely monitor and assist multiple patients ${ }^{34}$, will be increasingly important in the future ${ }^{4}$.

Despite the potential advantages of deploying digital technology to both dementia research and care, it carries ethical implications. Consent, and capacity, is particularly relevant given the potential security and privacy threats associated with intelligent technology ${ }^{43}$. Patient confidentiality may be violated by an intrusion upon, or revelation of, something private; such violations are considered to include use of video or audio technology ${ }^{35}$ and content of feedback given to carers. While data collected should be secure and encrypted to maintain confidentiality, there are inherent security risks when collecting and transferring personal data via a network ${ }^{43}$. Privacy and security are major considerations in user adoption of digital technology, with higher acceptance reported for noninvasive, reliable equipment ${ }^{40}$.

A further ethical concern is socioeconomic barriers that may prevent utilisation of digital technology for healthcare across society ${ }^{4}$. While few of the reviewed studies reported any costs of the technologies implemented, it is unlikely to be trivial. Beyond the initial hardware cost, further hidden costs associated with technology usage, update and protection (for example internet access and insurance policies) may cause a socioeconomic divide. Such finances need to be managed, and with cognitive decline often affecting ADLs such as financial organisation ${ }^{35}{ }^{36}$ the burden associated with introducing smart technology may be considerable and infeasible. Nevertheless, digital monitoring of those with cognitive decline may provide a lower-cost alternative to full-time care ${ }^{34}$. 
These arguments highlight the need for research investigating the cost-benefit ratio of technologies and variations between demographic groups.

Although out of this reviews scope, it is worth mentioning there are many new digital technologies on the horizon which could be adopted for dementia care. One such development, broadly referred to as 'bodyNET'44, involves a network of sensors and smart devices worn as part of clothing, on the skin, or even implanted into the body. This technology is early development but should allow for a passive data monitoring that can be used alongside the principles of assistive technology ${ }^{44}$. Other technologies are being specifically developed to target dementia-related deficits. One example is PARO ${ }^{45}$ : a socially-assistive robot seal pup, which has been shown to increase social interactions between dementia patients in a group therapy session. Another system, BikeAround ${ }^{46}$ employs a $^{2}$ stationary bike paired with a virtual-reality projection of Google Street View to allow dementia patients to "visit" personally significant locations and, in doing this, tap into their autobiographical memories.

In conclusion, developments in digital technology for the monitoring and assistance of older adults with and without a dementing disease is a rapidly growing area of interest. This technology has the potential to greatly improve the efficiency of dementia drug development, as well as optimise the provision of dementia care in settings of increasing demand. Many of the developments appear promising in their initial pilot stages, however further research is needed to validate the measures and assess long-term outcomes of users.

\section{Word Count: 3864}




\section{References}

1. Prince MJ. World Alzheimer Report 2015: the global impact of dementia: an analysis of prevalence, incidence, cost and trends: Alzheimer's Disease International 2015.

2. Wu YT, Beiser AS, Breteler MMB, et al. The changing prevalence and incidence of dementia over time - current evidence. Nat Rev Neurol 2017;13(6):327-39. doi: 10.1038/nrneurol.2017.63

3. Lewis FI, Torgerson PR. The current and future burden of late-onset dementia in the United Kingdom: Estimates and interventions. Alzheimers Dement 2017;13(1):38-44. doi: 10.1016/j.jalz.2016.03.013

4. lenca M, Fabrice J, Elger B, et al. Intelligent Assistive Technology for Alzheimer's Disease and Other Dementias: A Systematic Review. J Alzheimers Dis 2017;56(4):1301-40. doi: 10.3233/JAD161037

5. Demiris G, Hensel BK. Technologies for an aging society: a systematic review of "smart home" applications. Yearb Med Inform 2008:33-40.

6. Klimova B. Mobile Phone Apps in the Management and Assessment of Mild Cognitive Impairment and/or Mild-to-Moderate Dementia: An Opinion Article on Recent Findings. Front Hum Neurosci 2017;11:461. doi: 10.3389/fnhum.2017.00461

7. Luengo-Fernandez R, Leal J, Gray A. Dementia 2010: The economic burden of dementia and associated research funding in the United Kingdom. Cambridge: Alzheimer's Research Trust 2010

8. Shellington EM, Felfeli T, Shigematsu R, et al. HealtheBrain: an innovative smartphone application to improve cognitive function in older adults. Mhealth 2017;3:17. doi: 10.21037/mhealth.2017.04.05

9. Health NloM. Domain: Cognitive Systems [Available from: https://www.nimh.nih.gov/researchpriorities/rdoc/constructs/cognitive-systems.shtml accessed 06/11/2017 2017.

10. Shah TM, Weinborn M, Verdile G, et al. Enhancing Cognitive Functioning in Healthly Older Adults: a Systematic Review of the Clinical Significance of Commercially Available Computerized Cognitive Training in Preventing Cognitive Decline. Neuropsychol Rev 2017;27(1):62-80. doi: 10.1007/s11065-016-9338-9

11. Hill NL, Mogle J, Colancecco E, et al. Feasibility study of an attention training application for older adults. Int J Older People Nurs 2015;10(3):241-9. doi: 10.1111/opn.12092

12. Jongstra S, Wijsman LW, Cachucho R, et al. Cognitive Testing in People at Increased Risk of Dementia Using a Smartphone App: The iVitality Proof-of-Principle Study. JMIR Mhealth Uhealth 2017;5(5):e68. doi: 10.2196/mhealth.6939

13. Brouillette RM, Foil $\mathrm{H}$, Fontenot $\mathrm{S}$, et al. Feasibility, reliability, and validity of a smartphone based application for the assessment of cognitive function in the elderly. PLoS One 2013;8(6):e65925. doi: 10.1371/journal.pone.0065925

14. Tieges Z, Stiobhairt A, Scott K, et al. Development of a smartphone application for the objective detection of attentional deficits in delirium. Int Psychogeriatr 2015;27(8):1251-62. doi: $10.1017 /$ S1041610215000186

15. Hartin PJ, Nugent CD, McClean SI, et al. A smartphone application to evaluate technology adoption and usage in persons with dementia. Conf Proc IEEE Eng Med Biol SoC 2014;2014:5389-92. doi: 10.1109/EMBC.2014.6944844

16. Tschanz JT, Norton MC, Zandi PP, et al. The Cache County Study on Memory in Aging: factors affecting risk of Alzheimer's disease and its progression after onset. Int Rev Psychiatry 2013;25(6):673-85. doi: 10.3109/09540261.2013.849663

17. Oh SJ, Seo S, Lee JH, et al. Effects of smartphone-based memory training for older adults with subjective memory complaints: a randomized controlled trial. Aging Ment Health 2017:1-9. doi: 10.1080/13607863.2016.1274373

18. Shin M, Kwon J. Memory Diagnostic System (MDS). Seoul: Brain Medic Co, Ltd 2014

19. Hill NL, Mogle J, Wion R, et al. App-based attention training: Incorporating older adults' feedback to facilitate home-based use. Int J Older People Nurs 2017 doi: 10.1111/opn.12163 
20. Teixeira CV, Gobbi S, Pereira JR, et al. Effects of square-stepping exercise on cognitive functions of older people. Psychogeriatrics 2013;13(3):148-56. doi: 10.1111/psyg.12017

21. Cachia C, Attard C, Montebello M. WanderRep: a reporting tool for caregivers of wandering persons with dementia. 2014

22. Netscher G. Applications of Machine Learning to Support Dementia Care through Commercially Available Off-the-Shelf Sensing. University of California, Berkeley, 2016.

23. Shin $D$, Shin $D$, Shin D. Ubiquitous health management system with watch-type monitoring device for dementia patients. Journal of Applied Mathematics 2014;2014

24. The use of smartwatches for health monitoring in home-based dementia care. International Conference on Human Aspects of IT for the Aged Population; 2015. Springer.

25. Possin KL, Merrilees J, Bonasera SJ, et al. Development of an adaptive, personalized, and scalable dementia care program: Early findings from the Care Ecosystem. PLoS Med 2017;14(3):e1002260. doi: 10.1371/journal.pmed.1002260

26. Ahanathapillai V, Amor J, James C. Assistive technology to monitor activity, health and wellbeing in old age: The wrist wearable unit in the USEFIL project. Technology and Disability 2015;27(1, 2):17-29.

27. Stubbs B, Chen LJ, Chang CY, et al. Accelerometer-assessed light physical activity is protective of future cognitive ability: A longitudinal study among community dwelling older adults. Exp Gerontol 2017;91:104-09. doi: 10.1016/j.exger.2017.03.003

28. Gorman E, Hanson HM, Yang PH, et al. Accelerometry analysis of physical activity and sedentary behavior in older adults: a systematic review and data analysis. Eur Rev Aging Phys Act 2014;11:35-49. doi: 10.1007/s11556-013-0132-x

29. Galvin JE, Roe CM, Powlishta KK, et al. The AD8: a brief informant interview to detect dementia. Neurology 2005;65(4):559-64. doi: 10.1212/01.wnl.0000172958.95282.2a

30. Matthews JT, Campbell GB, Hunsaker AE, et al. Wearable Technology to Garner the Perspective of Dementia Family Caregivers. J Gerontol Nurs 2016;42(4):16-22. doi: 10.3928/0098913420151008-65

31. Thorpe JR, Ronn-Andersen KV, Bien P, et al. Pervasive assistive technology for people with dementia: a UCD case. Healthc Technol Lett 2016;3(4):297-302. doi: 10.1049/htl.2016.0057

32. Browne G, Berry E, Kapur N, et al. SenseCam improves memory for recent events and quality of life in a patient with memory retrieval difficulties. Memory 2011;19(7):713-22. doi: 10.1080/09658211.2011.614622

33. Conceptual Design and Implementation of Indicator-based Smart Glasses: A navigational device for remote assistance of senior citizens suffering from memory loss. Medical Information and Communication Technology (ISMICT), 2015 9th International Symposium on; 2015. IEEE.

34. Arcelus A, Howell Jones M, Goubran R, et al. Integration of Smart Home Technologies in a Health Monitoring System for the Elderly2007.

35. Stavropoulos TG, Meditskos G, Kompatsiaris I. DemaWare2: Integrating sensors, multimedia and semantic analysis for the ambient care of dementia. Pervasive and Mobile Computing 2017;34(Supplement C):126-45. doi: https://doi.org/10.1016/i.pmcj.2016.06.006

36. Dawadi PN, Cook DJ, Schmitter-Edgecombe M, et al. Automated assessment of cognitive health using smart home technologies. Technol Health Care 2013;21(4):323-43. doi: 10.3233/THC130734

37. Hall A, Wilson CB, Stanmore E, et al. Implementing monitoring technologies in care homes for people with dementia: A qualitative exploration using Normalization Process Theory. Int J Nurs Stud 2017;72:60-70. doi: 10.1016/j.ijnurstu.2017.04.008

38. Ishii H, Kimino K, Aljehani M, et al. An Early Detection System for Dementia Using the M2 M/loT Platform. Procedia Computer Science 2016;96(Supplement C):1332-40. doi: https://doi.org/10.1016/i.procs.2016.08.178 
39. Lyons BE, Austin D, Seelye A, et al. Pervasive Computing Technologies to Continuously Assess Alzheimer's Disease Progression and Intervention Efficacy. Front Aging Neurosci 2015;7:102. doi: 10.3389/fnagi.2015.00102

40. Kaye J, Mattek N, Dodge HH, et al. Unobtrusive measurement of daily computer use to detect mild cognitive impairment. Alzheimers Dement 2014;10(1):10-7. doi: 10.1016/j.jalz.2013.01.011

41. L HT, N L, A A, et al. Medication adherence in healthy elders: small cognitive changes make a big difference. J Aging Health 2009;21(4):657-580. doi: 10.1177/0898264309332836

42. Acevedo A, Loewenstein DA. Nonpharmacological cognitive interventions in aging and dementia. Journal of Geriatric Psychiatry and Neurology 2007;20(4):239-49.

43. O'Gorman T. A Primer on IoT Security Risks Security Intelligence - Analysis and Insight for Information Security Professionals: IBM; 2017 [Available from: https://securityintelligence.com/a-primer-on-iot-security-risks/ accessed 24/10/2017 2017.

44. Chu B, Burnett W, Chung JW, et al. Bring on the bodyNET. Nature 2017;549(7672):328-30. doi: 10.1038/549328a

45. Sabanovic S, Bennett CC, Chang WL, et al. PARO robot affects diverse interaction modalities in group sensory therapy for older adults with dementia. IEEE Int Conf Rehabil Robot 2013;2013:6650427. doi: 10.1109/ICORR.2013.6650427

46. Hertz A. A ride to remember on World Alzheimer's Day. The Keyword. Maps: Google Blog, 2017.

Table 1. Digital technology index: Summary of studies included in clinical review. Abbreviations: Activities of daily living (ADL), Alzheimer's Disease (AD), Area under the curve (AUC), Clinical Dementia Rating (CDR), Colour-Shape Test (CST), Global positioning system (GPS), Interquartile range (IQR), Light emitting diode (LED), Mild Cognitive Impairment (MCI), Mini-Mental State Examination (MMSE), Receiver operating characteristic (ROC), Smartphone-based brain Anti-Ageing and memory Reinforcement Training (SMART), Standard Deviation (SD), Trail Making Tests (TMT).

\begin{tabular}{|c|c|c|c|c|c|c|c|}
\hline Study & $\begin{array}{l}\text { Techno } \\
\text { logy } \\
\text { name }\end{array}$ & $\begin{array}{l}\text { Techno } \\
\text { logy } \\
\text { type }\end{array}$ & $\begin{array}{l}\text { Cognitiv } \\
\text { e target }\end{array}$ & $\begin{array}{l}\text { Develop } \\
\text { ment } \\
\text { stage }\end{array}$ & $\begin{array}{l}\text { Particip } \\
\text { ants }\end{array}$ & $\begin{array}{l}\text { Primary } \\
\text { outcome }\end{array}$ & Result \\
\hline \multicolumn{8}{|c|}{ Smartphone Applications } \\
\hline $\begin{array}{l}\text { Brouillet } \\
\text { te et al. } \\
(2013)\end{array}$ & $\begin{array}{l}\text { Colour- } \\
\text { Shape } \\
\text { Test } \\
\text { (CST) } \\
\end{array}$ & $\begin{array}{l}\text { Smartp } \\
\text { hone } \\
\text { applica } \\
\text { tion }\end{array}$ & $\begin{array}{l}\text { Processi } \\
\text { ng } \\
\text { speed }\end{array}$ & $\begin{array}{l}\text { Proof- } \\
\text { of- } \\
\text { concept }\end{array}$ & $\begin{array}{l}57 \\
\text { healthy } \\
\text { older } \\
\text { adults. } \\
\text { Age: } \\
\text { mean } \\
67.18 \\
\text { years } \\
\text { (SD } \pm \\
1.02 \text { ) }\end{array}$ & $\begin{array}{l}\text { Comparison } \\
\text { of } \\
\text { performanc } \\
\text { e on app } \\
\text { with scores } \\
\text { on standard } \\
\text { assessments } \\
\text { of cognitive } \\
\text { processing } \\
\text { speed and } \\
\text { cognitive } \\
\text { function. } \\
\end{array}$ & $\begin{array}{l}\text { Scores on CST } \\
\text { significantly positively } \\
\text { correlated with global } \\
\text { cognition (as measured } \\
\text { by MMSE), processing } \\
\text { speed and attention (as } \\
\text { measured by digit span, } \\
\text { trail making and digit- } \\
\text { symbol test). Test- } \\
\text { retest reliability was } \\
\text { significant. }\end{array}$ \\
\hline $\begin{array}{l}\text { Hartin et } \\
\text { al. } \\
\text { (2014) }\end{array}$ & $\begin{array}{l}\text { Techno } \\
\text { logy } \\
\text { Adopti } \\
\text { on and } \\
\text { Usage } \\
\text { Tool } \\
\text { (TAUT) }\end{array}$ & $\begin{array}{l}\text { Smartp } \\
\text { hone } \\
\text { applica } \\
\text { tion }\end{array}$ & $\begin{array}{l}\text { Prospect } \\
\text { ive } \\
\text { memory }\end{array}$ & $\begin{array}{l}\text { Proof- } \\
\text { of- } \\
\text { concept }\end{array}$ & $\begin{array}{l}9 \\
\text { healthy } \\
\text { younger } \\
\text { adults. } \\
\text { Age: } \\
\text { median } \\
27 \text { years }\end{array}$ & $\begin{array}{l}\text { Adherence } \\
\text { to reminder } \\
\text { alerts }\end{array}$ & $\begin{array}{l}73 \% \text { of reminder alerts } \\
\text { were acknowledged } \\
\text { (within a mean } \\
\text { response time of } 12.38 \\
\text { seconds), despite } 80 \% \\
\text { of reminders } \\
\text { interrupting the } \\
\text { participant during } \\
\text { another activity. }\end{array}$ \\
\hline
\end{tabular}




\begin{tabular}{|c|c|c|c|c|c|c|c|}
\hline & & & & & & & $\begin{array}{l}\text { Reminders for all ADL } \\
\text { categories available } \\
\text { were used. }\end{array}$ \\
\hline $\begin{array}{l}\text { Hill et al. } \\
\text { (2017) }\end{array}$ & $\begin{array}{l}\text { Modifie } \\
d \\
\text { Attenti } \\
\text { on } \\
\text { Trainin } \\
\text { g } \\
\text { Applica } \\
\text { tion } \\
\text { (ATA) }\end{array}$ & $\begin{array}{l}\text { Tablet } \\
\text { applica } \\
\text { tion }\end{array}$ & $\begin{array}{l}\text { Attentio } \\
\mathrm{n}\end{array}$ & $\begin{array}{l}\text { Proof- } \\
\text { of- } \\
\text { concept }\end{array}$ & $\begin{array}{l}\text { 12 older } \\
\text { adults } \\
\text { without } \\
\text { moderat } \\
\text { e-severe } \\
\text { cognitiv } \\
\text { e } \\
\text { impairm } \\
\text { ent. } \\
\text { Age: } \\
\text { mean } 79 \\
\text { years } \\
\text { (SD } \pm \\
4.2 \text { ) }\end{array}$ & $\begin{array}{l}\text { Feedback on } \\
\text { the usability } \\
\text { and } \\
\text { acceptability } \\
\text { of the app } \\
\text { for attention } \\
\text { training. }\end{array}$ & $\begin{array}{l}\text { On average participants } \\
\text { rated the app positively } \\
\text { ( } 60 \% \text { or higher). A } \\
\text { preference for } \\
\text { challenge, speed and } \\
\text { variety was } \\
\text { demonstrated. Main } \\
\text { limitations included: } \\
\text { lack of engagement, } \\
\text { technical difficulties } \\
\text { and confusion } \\
\text { regarding use. }\end{array}$ \\
\hline $\begin{array}{l}\text { Jongstra } \\
\text { et al. } \\
\text { (2017) }\end{array}$ & iVitality & $\begin{array}{l}\text { Smartp } \\
\text { hone } \\
\text { applica } \\
\text { tion }\end{array}$ & $\begin{array}{l}\text { Working } \\
\text { \& short- } \\
\text { term } \\
\text { memory } \\
\text { ' } \\
\text { attentio } \\
\text { n, } \\
\text { executiv } \\
\text { e } \\
\text { function }\end{array}$ & $\begin{array}{l}\text { Proof- } \\
\text { of- } \\
\text { concept }\end{array}$ & $\begin{array}{l}151 \\
\text { healthy } \\
\text { older } \\
\text { adults } \\
\text { with } \\
\text { parental } \\
\text { history } \\
\text { of } \\
\text { dementi } \\
\text { a. Age: } \\
\text { mean } \\
57.3 \\
\text { years } \\
\text { (SD } \pm 5.3 \\
\text { ) }\end{array}$ & $\begin{array}{l}\text { Feasibility } \\
\text { and validity } \\
\text { of } \\
\text { smartphone- } \\
\text { based } \\
\text { neuropsych } \\
\text { ological } \\
\text { tests to } \\
\text { assess } \\
\text { various } \\
\text { aspects of } \\
\text { cognitive } \\
\text { function. }\end{array}$ & $\begin{array}{l}\text { The app version of the } \\
\text { Stroop and TMT } \\
\text { moderately correlated } \\
\text { with performance on } \\
\text { the conventional test } \\
\text { versions. Performance } \\
\text { on the app Stroop and } \\
\text { TMT reversed } \\
\text { alphanumeric tasks } \\
\text { improved with } \\
\text { repeated testing. Mean } \\
\text { adherence to assigned } \\
\text { smartphone tests was } \\
60 \% \text { at } 6 \text { months. }\end{array}$ \\
\hline $\begin{array}{l}\text { Oh et al } \\
\text { (2017) }\end{array}$ & $\begin{array}{l}\text { Smartp } \\
\text { hone- } \\
\text { based } \\
\text { brain } \\
\text { Anti- } \\
\text { Ageing } \\
\text { and } \\
\text { memor } \\
\text { y } \\
\text { Reinfor } \\
\text { cement } \\
\text { Trainin } \\
\text { g } \\
\text { (SMAR } \\
\text { T) and } \\
\text { FitBrain } \\
\text { sC }\end{array}$ & $\begin{array}{l}\text { Smartp } \\
\text { hone } \\
\text { applica } \\
\text { tions }\end{array}$ & $\begin{array}{l}\text { Attentio } \\
\mathrm{n} \text {, } \\
\text { working } \\
\text { memory } \\
\text { and } \\
\text { executiv } \\
\text { e } \\
\text { function }\end{array}$ & $\begin{array}{l}\text { Validati } \\
\text { on }\end{array}$ & $\begin{array}{l}53 \text { older } \\
\text { adults } \\
\text { with } \\
\text { subjecti } \\
\text { ve } \\
\text { memory } \\
\text { complai } \\
\text { nts. Age: } \\
\text { mean } \\
59.3 \\
\text { years } \\
\text { (SD } \pm \\
5.09 \text { ) }\end{array}$ & $\begin{array}{l}\text { Subjective } \\
\text { and } \\
\text { objective } \\
\text { improvemen } \\
\text { ts in } \\
\text { memory (as } \\
\text { measured } \\
\text { with } \\
\text { standard } \\
\text { questionnair } \\
\text { es) post-app } \\
\text { use. }\end{array}$ & $\begin{array}{l}\text { Total and auditory- } \\
\text { verbal working memory } \\
\text { scores increased } \\
\text { significantly in the } \\
\text { SMART group } \\
\text { compared to both } \\
\text { control groups. } \\
\text { However, self-reported } \\
\text { memory contentment } \\
\text { only significantly } \\
\text { improved in the } \\
\text { FitBrains group. }\end{array}$ \\
\hline
\end{tabular}




\begin{tabular}{|c|c|c|c|c|c|c|c|}
\hline $\begin{array}{l}\text { Shellingt } \\
\text { on et al. } \\
\text { (2017) }\end{array}$ & $\begin{array}{l}\text { Healthe } \\
\text { Brain }\end{array}$ & $\begin{array}{l}\text { Smartp } \\
\text { hone } \\
\text { applica } \\
\text { tion }\end{array}$ & $\begin{array}{l}\text { Visuosp } \\
\text { atial } \\
\text { memory }\end{array}$ & $\begin{array}{l}\text { Proof- } \\
\text { of- } \\
\text { concept }\end{array}$ & $\begin{array}{l}19 \\
\text { healthy } \\
\text { or mildly } \\
\text { cognitiv } \\
\text { ely } \\
\text { impaire } \\
\text { d older } \\
\text { adults. } \\
\text { Age: } \\
\text { mean } \\
68.3 \\
\text { years } \\
\text { (SD } \pm \\
5.4)\end{array}$ & $\begin{array}{l}\text { Feedback on } \\
\text { the usability } \\
\text { of the app to } \\
\text { deliver } \\
\text { exercise- } \\
\text { based, } \\
\text { visuospatial } \\
\text { tasks } \\
\text { outside the } \\
\text { lab. }\end{array}$ & $\begin{array}{l}19 / 95 \text { contacted } \\
\text { participants successfully } \\
\text { downloaded the app } \\
\text { and completed the } \\
\text { survey. } 60 \% \text { of } \\
\text { participants found the } \\
\text { app easy to use, or } \\
\text { similar to previous } \\
\text { experiences. } 9 \\
\text { participants said they } \\
\text { would continue to use } \\
\text { the app in the future. }\end{array}$ \\
\hline $\begin{array}{l}\text { Tieges } \\
\text { et al. } \\
\text { (2015) }\end{array}$ & DelApp & $\begin{array}{l}\text { Smartp } \\
\text { hone } \\
\text { applica } \\
\text { tion }\end{array}$ & $\begin{array}{l}\text { Visual } \\
\text { sustaine } \\
\mathrm{d} \\
\text { attentio } \\
\mathrm{n}\end{array}$ & $\begin{array}{l}\text { Proof- } \\
\text { of- } \\
\text { concept }\end{array}$ & $\begin{array}{l}156 \\
\text { older } \\
\text { hospital } \\
\text { inpatien } \\
\text { ts (50 } \\
\text { with } \\
\text { delirium } \\
\text {, } 52 \text { with } \\
\text { dementi } \\
\text { a and } 54 \\
\text { with no } \\
\text { cognitiv } \\
\text { e } \\
\text { impairm } \\
\text { ent). } \\
\text { Age: IQR } \\
70-91 \\
\text { years }\end{array}$ & $\begin{array}{l}\text { Ability of } \\
\text { smartphone } \\
\text { based test of } \\
\text { visual } \\
\text { sustained } \\
\text { attention to } \\
\text { reliably } \\
\text { differentiate } \\
\text { patients } \\
\text { with } \\
\text { delirium } \\
\text { from those } \\
\text { with } \\
\text { dementia. }\end{array}$ & $\begin{array}{l}\text { DelApp scores differed } \\
\text { significantly between all } \\
3 \text { groups } \\
\text { (delirium<dementia<co } \\
\text { ntrols). ROC analyses } \\
\text { revealed excellent } \\
\text { accuracy of the DelApp } \\
\text { for discriminating } \\
\text { delirium from dementia } \\
\text { (AUC }=0.93 \text { ), and } \\
\text { delirium from controls } \\
\text { (AUC }=0.99 \text { ). }\end{array}$ \\
\hline \multicolumn{8}{|c|}{ Wearables } \\
\hline $\begin{array}{l}\text { Ahanath } \\
\text { apillai et } \\
\text { al. } \\
(2015)\end{array}$ & $\begin{array}{l}\text { Wrist } \\
\text { Weara } \\
\text { ble } \\
\text { Unit } \\
\text { (WWU) }\end{array}$ & $\begin{array}{l}\text { Smartw } \\
\text { atch } \\
\text { system }\end{array}$ & $\begin{array}{l}\text { Activitie } \\
\text { s of } \\
\text { daily } \\
\text { living }\end{array}$ & $\begin{array}{l}\text { Proof- } \\
\text { of- } \\
\text { concept }\end{array}$ & $\begin{array}{l}\text { Healthy } \\
\text { younger } \\
\text { adults. } \\
\text { Age: } \\
\text { range } \\
20-50 \\
\text { years }\end{array}$ & $\begin{array}{l}\text { Ability of } \\
\text { system to } \\
\text { detect and } \\
\text { record } \\
\text { activity } \\
\text { related } \\
\text { measures in } \\
\text { order to } \\
\text { infer } \\
\text { behavioural } \\
\text { patterns. }\end{array}$ & $\begin{array}{l}\text { Activity level } \\
\text { calculations from long } \\
\text { term device usage, } \\
\text { correlated with } \\
\text { participants' self- } \\
\text { reported activity levels. }\end{array}$ \\
\hline $\begin{array}{l}\text { Boletsis } \\
\text { et al. } \\
\text { (2015) }\end{array}$ & $\begin{array}{l}\text { Basis } \\
\text { B1 } \\
\text { Smartw } \\
\text { atch }\end{array}$ & $\begin{array}{l}\text { Smartw } \\
\text { atch } \\
\text { system }\end{array}$ & $\begin{array}{l}\text { Activitie } \\
\text { s of } \\
\text { daily } \\
\text { living }\end{array}$ & $\begin{array}{l}\text { Proof- } \\
\text { of- } \\
\text { concept }\end{array}$ & $\begin{array}{l}1 \\
\text { patient } \\
\text { with } \\
\text { advance } \\
\text { d } \\
\text { dementi } \\
\text { a and } 1\end{array}$ & $\begin{array}{l}\text { Feasibility } \\
\text { and validity } \\
\text { of } \\
\text { smartwatch- } \\
\text { based } \\
\text { measures to } \\
\text { assess daily } \\
\end{array}$ & $\begin{array}{l}\text { Caregiver able to } \\
\text { extract useful } \\
\text { information about } \\
\text { patterns in patient's } \\
\text { behaviour (sleep, } \\
\text { exertion) and changes } \\
\text { to this pattern. Issue }\end{array}$ \\
\hline
\end{tabular}




\begin{tabular}{|c|c|c|c|c|c|c|c|}
\hline & & & & & $\begin{array}{l}\text { professi } \\
\text { onal } \\
\text { caregive } \\
r\end{array}$ & $\begin{array}{l}\text { activity } \\
\text { function. }\end{array}$ & $\begin{array}{l}\text { with steps not } \\
\text { registering when } \\
\text { patient used a walking } \\
\text { frame support. }\end{array}$ \\
\hline $\begin{array}{l}\text { Browne } \\
\text { et al. } \\
\text { (2011) }\end{array}$ & $\begin{array}{l}\text { SenseC } \\
\text { am }\end{array}$ & $\begin{array}{l}\text { Weara } \\
\text { ble } \\
\text { camera } \\
\text { system }\end{array}$ & $\begin{array}{l}\text { Declarat } \\
\text { ive } \\
\text { memory }\end{array}$ & $\begin{array}{l}\text { Proof- } \\
\text { of- } \\
\text { concept }\end{array}$ & $\begin{array}{l}1 \text { adult } \\
\text { with } \\
\text { mild } \\
\text { cognitiv } \\
\text { e } \\
\text { impairm } \\
\text { ent. } \\
\text { Age: } 56 \\
\text { years }\end{array}$ & $\begin{array}{l}\text { Efficacy of } \\
\text { camera } \\
\text { system to } \\
\text { aid recall of } \\
\text { significant } \\
\text { personal } \\
\text { events. }\end{array}$ & $\begin{array}{l}\text { The proportion of } \\
\text { events recalled was } \\
\text { significantly higher over } \\
2 \text { weeks when using the } \\
\text { SenseCam review } \\
(68 \%) \text {, than when } \\
\text { relying on a diary ( } 38 \%) \\
\text { or not actively cueing } \\
\text { memory (30\%). At } 6 \\
\text { months this difference } \\
\text { in recall between } \\
\text { groups was still present. }\end{array}$ \\
\hline $\begin{array}{l}\text { Cachia } \\
\text { et al. } \\
\text { (2014) }\end{array}$ & $\begin{array}{l}\text { Wande } \\
\text { rRep }\end{array}$ & $\begin{array}{l}\text { Smartw } \\
\text { atch } \\
\text { system }\end{array}$ & $\begin{array}{l}\text { Wanderi } \\
\mathrm{ng}\end{array}$ & $\begin{array}{l}\text { Proof- } \\
\text { of- } \\
\text { concept }\end{array}$ & $\begin{array}{l}1 \\
\text { patient } \\
\text { with } \\
\text { dementi } \\
\text { a and } 5 \\
\text { professi } \\
\text { onal } \\
\text { caregive } \\
\text { rs } \\
\end{array}$ & $\begin{array}{l}\text { Ability of } \\
\text { system to } \\
\text { differentiate } \\
\text { dangerous } \\
\text { wandering } \\
\text { scenarios } \\
\text { from normal } \\
\text { movement } \\
\text { and activity. }\end{array}$ & $\begin{array}{l}\text { WanderRep had a } 78 \% \\
\text { sensitivity to detect } \\
\text { pre-determined } \\
\text { dangerous scenarios } \\
\text { based on temperature, } \\
\text { activity level, location } \\
\text { and time. }\end{array}$ \\
\hline $\begin{array}{l}\text { Firouzia } \\
\mathrm{n} \text { et al. } \\
\text { (2015) }\end{array}$ & $\begin{array}{l}\text { Indicat } \\
\text { or- } \\
\text { based } \\
\text { Smart } \\
\text { Glasses }\end{array}$ & $\begin{array}{l}\text { Smart } \\
\text { glasses }\end{array}$ & $\begin{array}{l}\text { Navigati } \\
\text { on }\end{array}$ & Design & $\begin{array}{l}\text { Not } \\
\text { specifie } \\
\text { d }\end{array}$ & $\begin{array}{l}\text { Usability of } \\
\text { smart } \\
\text { glasses } \\
\text { system to } \\
\text { provide } \\
\text { visual, } \\
\text { navigational } \\
\text { cues. }\end{array}$ & $\begin{array}{l}\text { The most } \\
\text { distinguishable } \\
\text { positions, frequency } \\
\text { and brightness of LED } \\
\text { lights for forming visual } \\
\text { cues were determined. } \\
\text { Need to develop and } \\
\text { pilot a user-friendly } \\
\text { interface and more } \\
\text { lightweight device. }\end{array}$ \\
\hline $\begin{array}{l}\text { Matthe } \\
\text { ws et al. } \\
\text { (2016) }\end{array}$ & & $\begin{array}{l}\text { Weara } \\
\text { ble } \\
\text { camera } \\
\text { system }\end{array}$ & $\begin{array}{l}\text { Activitie } \\
\text { s of } \\
\text { daily } \\
\text { living }\end{array}$ & $\begin{array}{l}\text { Proof- } \\
\text { of- } \\
\text { concept }\end{array}$ & $\begin{array}{l}18 \\
\text { people } \\
\text { with } \\
\text { dementi } \\
\text { a (age: } \\
\text { mean } \\
78.6 \\
\text { years, } \\
\text { SD } \pm 9.1 \text { ) } \\
\text { and } \\
\text { their } \\
\text { primary } \\
\text { caregive } \\
\text { rs (age: } \\
\text { mean } \\
63.7\end{array}$ & $\begin{array}{l}\text { Ability of the } \\
\text { system to } \\
\text { capture } \\
\text { episodes of } \\
\text { dementia- } \\
\text { related } \\
\text { behaviour or } \\
\text { caregiving } \\
\text { interactions. }\end{array}$ & $\begin{array}{l}\text { A total of } 341 \text { hours of } \\
\text { usable video was } \\
\text { obtained, yielding } \\
\text { capture of } 248 \text { salient } \\
\text { events. }\end{array}$ \\
\hline
\end{tabular}




\begin{tabular}{|c|c|c|c|c|c|c|c|}
\hline & & & & & $\begin{array}{l}\text { years, } \\
S D \pm \\
14.0)\end{array}$ & & \\
\hline $\begin{array}{l}\text { Netsche } \\
r(2015)\end{array}$ & Max & $\begin{array}{l}\text { Smartw } \\
\text { atch } \\
\text { system }\end{array}$ & $\begin{array}{l}\text { Activitie } \\
\text { s of } \\
\text { daily } \\
\text { living }\end{array}$ & $\begin{array}{l}\text { Proof- } \\
\text { of- } \\
\text { concept }\end{array}$ & $\begin{array}{l}13 \\
\text { healthy } \\
\text { participa } \\
\text { nts from } \\
\text { the } \\
\text { Dementi } \\
\text { a Care } \\
\text { Ecosyste } \\
\text { m study }\end{array}$ & $\begin{array}{l}\text { Ability of } \\
\text { system to } \\
\text { measure } \\
\text { users' } \\
\text { routine } \\
\text { behavioural } \\
\text { patterns and } \\
\text { detect } \\
\text { outliers or } \\
\text { declining } \\
\text { trends. }\end{array}$ & $\begin{array}{l}\text { Room detection } \\
\text { accuracy } 96.1 \% \pm 2.6 \% \text {. } \\
\text { Reliable behaviour } \\
\text { modelling possible with } \\
\text { missing data i.e. when } \\
\text { the user forgot/chose } \\
\text { not to wear the device. }\end{array}$ \\
\hline $\begin{array}{l}\text { Shin et } \\
\text { al. } \\
\text { (2014) }\end{array}$ & $\begin{array}{l}\text { u- } \\
\text { Healthc } \\
\text { are }\end{array}$ & $\begin{array}{l}\text { Smartw } \\
\text { atch } \\
\text { system }\end{array}$ & $\begin{array}{l}\text { Activitie } \\
\text { s of } \\
\text { daily } \\
\text { living }\end{array}$ & $\begin{array}{l}\text { Proof- } \\
\text { of- } \\
\text { concept }\end{array}$ & $\begin{array}{l}8 \\
\text { participa } \\
\text { nts }\end{array}$ & $\begin{array}{l}\text { Ability of the } \\
\text { system to } \\
\text { monitor } \\
\text { users' } \\
\text { location, } \\
\text { physical } \\
\text { activity and } \\
\text { sun } \\
\text { exposure. }\end{array}$ & $\begin{array}{l}\text { The system had on } \\
\text { average a } 94.7 \% \\
\text { accuracy in detecting } \\
\text { steps. User profiles of } \\
\text { activity were then } \\
\text { produced based on } \\
\text { steps, demographic } \\
\text { information, GPS } \\
\text { information and light } \\
\text { sensor data. }\end{array}$ \\
\hline $\begin{array}{l}\text { Stubbs } \\
\text { et al. } \\
\text { (2017) }\end{array}$ & & $\begin{array}{l}\text { Weara } \\
\text { ble } \\
\text { acceler } \\
\text { ometer } \\
\text { system }\end{array}$ & $\begin{array}{l}\text { Activitie } \\
\text { s of } \\
\text { daily } \\
\text { living }\end{array}$ & $\begin{array}{l}\text { Validate } \\
\text { d }\end{array}$ & $\begin{array}{l}274 \\
\text { commun } \\
\text { ity- } \\
\text { dwelling } \\
\text { older } \\
\text { adults. } \\
\text { Age: } \\
\text { mean } \\
74.52 \\
\text { years } \\
\text { (SD } \pm \\
6.12 \text { ) }\end{array}$ & $\begin{array}{l}\text { Efficacy of } \\
\text { objectively } \\
\text { measured } \\
\text { levels of } \\
\text { physical } \\
\text { activity to } \\
\text { predict } \\
\text { cognitive } \\
\text { stability in } \\
\text { older adults. }\end{array}$ & $\begin{array}{l}\text { Light and moderate } \\
\text { physical activity as } \\
\text { measured by the } \\
\text { accelerometer were } \\
\text { both significantly } \\
\text { associated with a } \\
\text { reduced rate of } \\
\text { cognitive decline over } 2 \\
\text { years, with light } \\
\text { physical activity } \\
\text { associated } \\
\text { independently. }\end{array}$ \\
\hline $\begin{array}{l}\text { Thorpe } \\
\text { et al. } \\
\text { (2016) }\end{array}$ & & $\begin{array}{l}\text { Smartp } \\
\text { hone } \\
\text { applica } \\
\text { tions } \\
\text { and } \\
\text { smartw } \\
\text { atch } \\
\text { system }\end{array}$ & $\begin{array}{l}\text { Activitie } \\
\text { s of } \\
\text { daily } \\
\text { living }\end{array}$ & $\begin{array}{l}\text { Proof- } \\
\text { of- } \\
\text { concept }\end{array}$ & $\begin{array}{l}5 \\
\text { patients } \\
\text { with } \\
\text { dementi } \\
\text { a and } \\
\text { their } \\
\text { spouses. } \\
\text { Age: } \\
\text { range } 61 \\
\text { to } 73 \\
\text { years. }\end{array}$ & $\begin{array}{l}\text { Usability of } \\
\text { integrated } \\
\text { wearable } \\
\text { and } \\
\text { smartphone } \\
\text { system to } \\
\text { assist people } \\
\text { with } \\
\text { dementia } \\
\text { with } \\
\text { completion } \\
\text { of daily } \\
\text { activities. }\end{array}$ & $\begin{array}{l}\text { Scheduling, } \\
\text { communication and } \\
\text { orientation tasks had a } \\
100 \% \text { completion rate, } \\
\text { but navigation/ } \\
\text { emergency help tasks } \\
\text { had a } 0 \% \text { completion } \\
\text { rate. }\end{array}$ \\
\hline
\end{tabular}




\begin{tabular}{|c|c|c|c|c|c|c|c|}
\hline \multicolumn{8}{|l|}{ nart $\mathrm{HC}$} \\
\hline $\begin{array}{l}\text { Arcelus } \\
\text { et al. } \\
\text { (2007) }\end{array}$ & $\begin{array}{l}\text { Techno } \\
\text { logy } \\
\text { Assiste } \\
d \\
\text { Friendl } \\
\text { y } \\
\text { Environ } \\
\text { ment } \\
\text { for the } \\
\text { Third } \\
\text { age } \\
\text { (TEFET } \\
\text { A) }\end{array}$ & $\begin{array}{l}\text { Smart } \\
\text { home }\end{array}$ & $\begin{array}{l}\text { Activitie } \\
\text { s of } \\
\text { daily } \\
\text { living }\end{array}$ & Design & $\begin{array}{l}\text { No } \\
\text { formal } \\
\text { data } \\
\text { collectio } \\
\mathrm{n}\end{array}$ & $\begin{array}{l}\text { Investigating } \\
\text { the benefits } \\
\text { and } \\
\text { limitation of } \\
\text { the design. }\end{array}$ & $\begin{array}{l}\text { May provide more } \\
\text { independence for users, } \\
\text { be an economical } \\
\text { alternative to } 24 \text { hour } \\
\text { care, and able to detect } \\
\text { subtle changes in } \\
\text { behaviour. However it } \\
\text { could be considered } \\
\text { intrusive, be rejected by } \\
\text { users uncomfortable } \\
\text { with technology or } \\
\text { users may develop a } \\
\text { false dependency on } \\
\text { the technology. }\end{array}$ \\
\hline $\begin{array}{l}\text { Hall et } \\
\text { al. } \\
\text { (2017) }\end{array}$ & & $\begin{array}{l}\text { Smart } \\
\text { home }\end{array}$ & $\begin{array}{l}\text { Activitie } \\
\text { s of } \\
\text { daily } \\
\text { living }\end{array}$ & $\begin{array}{l}\text { Validati } \\
\text { on }\end{array}$ & $\begin{array}{l}24 \text { care } \\
\text { staff, } \\
\text { age: } \\
\text { mean } \\
39.75 ; 3 \\
\text { resident } \\
\text { s with } \\
\text { dementi } \\
\text { a, age: } \\
\text { mean } \\
81.33 ; 9 \\
\text { relatives } \\
\text {, age: } \\
\text { mean } \\
55.67\end{array}$ & $\begin{array}{l}\text { Explore } \\
\text { facilitators } \\
\text { and barriers } \\
\text { to the } \\
\text { implementat } \\
\text { ion of } \\
\text { monitoring } \\
\text { technology. }\end{array}$ & $\begin{array}{l}\text { Core reason for use was } \\
\text { to enhance resident } \\
\text { safety and freedom, } \\
\text { outweighing ethical } \\
\text { concerns; technology } \\
\text { was perceived as simple } \\
\text { to use, but staff wanted } \\
\text { more formal training. } \\
\text { Frequent alarms were } \\
\text { generate and staff had } \\
\text { to rely on contextual } \\
\text { knowledge to decide } \\
\text { when to respond. }\end{array}$ \\
\hline $\begin{array}{l}\text { Stravrop } \\
\text { oulos et } \\
\text { al., } \\
(2016)\end{array}$ & $\begin{array}{l}\text { Dema } \\
\text { Ware2 }\end{array}$ & $\begin{array}{l}\text { Smart } \\
\text { home } \\
\text { data } \\
\text { modelli } \\
\text { ng } \\
\text { framew } \\
\text { ork }\end{array}$ & $\begin{array}{l}\text { Activitie } \\
\text { s of } \\
\text { daily } \\
\text { living }\end{array}$ & $\begin{array}{l}\text { Validati } \\
\text { on }\end{array}$ & $\begin{array}{l}98 \mathrm{AD}, \\
\mathrm{MCl} \text { or } \\
\text { control } \\
\text { participa } \\
\text { nts in } \\
\text { lab } \\
\text { environ } \\
\text { ment } \\
\text { (age: } \\
\text { range } \\
60-90 \text { ); } \\
2 \\
\text { amnesic } \\
\text { and 2 } \\
\text { dementi } \\
\text { a in } \\
\text { residenti } \\
\text { al } \\
\text { environ } \\
\text { ment }\end{array}$ & $\begin{array}{l}\text { Evaluation } \\
\text { of } \\
\text { DemaWare2 } \\
\text { modelling in } \\
\text { recognising } \\
\text { ADL in } \\
\text { laboratory } \\
\text { and } \\
\text { residential } \\
\text { environment } \\
\text { s. }\end{array}$ & $\begin{array}{l}\text { Activity recognition } \\
\text { recall and precision } \\
\text { close to } 82 \% \text { in lab- } \\
\text { environment and } 83 \% \\
\text { and } 76 \% \text { (respectively) } \\
\text { in residential } \\
\text { environment for most } \\
\text { ADL; however, } \\
\text { recognition varies } \\
\text { depending on ADL. Can } \\
\text { differentiate cognitively } \\
\text { healthy, } \mathrm{MCl} \text { and } \mathrm{AD} \\
\text { patients with up to } 84 \% \\
\text { accuracy. High user } \\
\text { acceptability. }\end{array}$ \\
\hline
\end{tabular}




\begin{tabular}{|c|c|c|c|c|c|c|c|}
\hline $\begin{array}{l}\text { Ishii et } \\
\text { al. } \\
\text { (2016) }\end{array}$ & $\begin{array}{l}\text { M2M } \\
\text { (Machi } \\
\text { ne-to- } \\
\text { Machin } \\
\text { e)/ loT } \\
\text { (Intern } \\
\text { et of } \\
\text { Things) } \\
\text { platfor } \\
\text { m }\end{array}$ & $\begin{array}{l}\text { Smart } \\
\text { home } \\
\text { data } \\
\text { modelli } \\
\text { ng } \\
\text { framew } \\
\text { ork }\end{array}$ & $\begin{array}{l}\text { Activitie } \\
\text { s of } \\
\text { daily } \\
\text { living }\end{array}$ & $\begin{array}{l}\text { Validati } \\
\text { on }\end{array}$ & $\begin{array}{l}\text { Pseudo } \\
\text { patient } \\
\text { data }\end{array}$ & $\begin{array}{l}\text { Evaluation } \\
\text { of modelling } \\
\text { platform in } \\
\text { recognising } \\
\text { ADL. }\end{array}$ & $\begin{array}{l}\text { Accuracy rate in } \\
\text { determining behaviour } \\
\text { was between } 80-100 \% \\
\text { for most activities but } \\
\text { was lower ( } 30-40 \% \\
\text { accuracy) for forgetting } \\
\text { to turn off the TV. }\end{array}$ \\
\hline $\begin{array}{l}\text { Dawadi } \\
\text { et al. } \\
\text { (2013) }\end{array}$ & & $\begin{array}{l}\text { Smart } \\
\text { home } \\
\text { data } \\
\text { modelli } \\
\text { ng } \\
\text { framew } \\
\text { ork }\end{array}$ & $\begin{array}{l}\text { Activitie } \\
\text { s of } \\
\text { daily } \\
\text { living }\end{array}$ & $\begin{array}{l}\text { Validati } \\
\text { on }\end{array}$ & $\begin{array}{l}16 \\
\text { dementi } \\
\text { a } \\
\text { patients, } \\
51 \mathrm{MCl} \\
\text { and } 196 \\
\text { cognitiv } \\
\text { ely } \\
\text { healthy } \\
\text { participa } \\
\text { nts } \\
\text { grouped } \\
\text { in } 4 \text { age } \\
\text { ranges }\end{array}$ & $\begin{array}{l}\text { Evaluating } \\
\text { modelling } \\
\text { framework } \\
\text { in making } \\
\text { ADL } \\
\text { performanc } \\
\text { e } \\
\text { predictions } \\
\text { compared to } \\
\text { clinical } \\
\text { observations } \\
\text { and } \\
\text { capability of } \\
\text { dementia } \\
\text { status } \\
\text { predictions. }\end{array}$ & $\begin{array}{l}\text { A correlation ( } r=.54 \text { ) } \\
\text { between the direct } \\
\text { observation scores and } \\
\text { predicted activity } \\
\text { quality when combining } \\
\text { scores from all } 8 \\
\text { activities; individual } \\
\text { activity correlations } \\
\text { varied. Reasonable } \\
\text { classification accuracy } \\
\text { in classifying } \\
\text { participants into } \\
\text { groups: dementia and } \\
\text { cognitively healthy but } \\
\text { not } \mathrm{MCl} \text {. }\end{array}$ \\
\hline $\begin{array}{l}\text { Lyons et } \\
\text { al. } \\
\text { (2015) }\end{array}$ & $\begin{array}{l}\text { Oregon } \\
\text { Center } \\
\text { for } \\
\text { Aging } \\
\text { and } \\
\text { Techno } \\
\text { logy } \\
\text { (ORCAT } \\
\text { ECH) }\end{array}$ & $\begin{array}{l}\text { Smart } \\
\text { Home }\end{array}$ & $\begin{array}{l}\text { Activitie } \\
\text { s of } \\
\text { daily } \\
\text { living }\end{array}$ & $\begin{array}{l}\text { Longitud } \\
\text { inal } \\
\text { cohort } \\
\text { study }\end{array}$ & $\begin{array}{l}480 \\
\text { smart } \\
\text { homes; } \\
\text { Users } \\
\text { over the } \\
\text { age of } \\
70, \\
\text { MMSE> } \\
24, \text { CDR } \\
<0.5 \text {, on } \\
\text { enrolme } \\
\text { nt. }\end{array}$ & $\begin{array}{l}\text { Presenting } \\
\text { results from } \\
\text { the last } 8 \\
\text { years. }\end{array}$ & $\begin{array}{l}\text { ADL results for sleep, } \\
\text { computer use, } \\
\text { medication adherence, } \\
\text { movement, social } \\
\text { engagement and a } \\
\text { multi-domain approach } \\
\text { have been used to } \\
\text { predict outcomes such } \\
\text { as low mood, } \\
\text { loneliness, and } \\
\text { cognitive function; } \\
\text { potential shown to } \\
\text { improve quality of } \\
\text { patient data related to } \\
\text { cognitive decline. }\end{array}$ \\
\hline $\begin{array}{l}\text { Kaye et } \\
\text { al. } \\
(2014)\end{array}$ & $\begin{array}{l}\text { Oregon } \\
\text { Center } \\
\text { for } \\
\text { Aging } \\
\text { and } \\
\text { Techno } \\
\text { logy } \\
\text { (ORCAT } \\
\text { ECH) }\end{array}$ & $\begin{array}{l}\text { Smart } \\
\text { Home }\end{array}$ & $\begin{array}{l}\text { Activity } \\
\text { of daily } \\
\text { living }\end{array}$ & $\begin{array}{l}\text { Longitud } \\
\text { inal } \\
\text { cohort } \\
\text { study }\end{array}$ & $\begin{array}{l}38 \mathrm{MCl} \\
\text { patients, } \\
\text { age: } \\
\text { mean } \\
84.6 \text { (SD } \\
\pm 4.8), \\
75 \\
\text { cognitiv } \\
\text { ely } \\
\text { healthy }\end{array}$ & $\begin{array}{l}\text { Assessing } \\
\text { ability of } \\
\text { unobtrusive } \\
\text { smart home } \\
\text { to monitor } \\
\text { computer } \\
\text { use, detect } \\
\text { mild } \\
\text { functional }\end{array}$ & $\begin{array}{l}\text { No difference in } \\
\text { computer use at } \\
\text { baseline, but years } 2 \\
\text { and } 3 \text { showed } \\
\text { significant decrease in } \\
\text { number of days with } \\
\text { use, mean daily use and } \\
\text { increase in day-to-day } \\
\text { variability in computer } \\
\text { use for } \mathrm{MCl} \text { compared }\end{array}$ \\
\hline
\end{tabular}




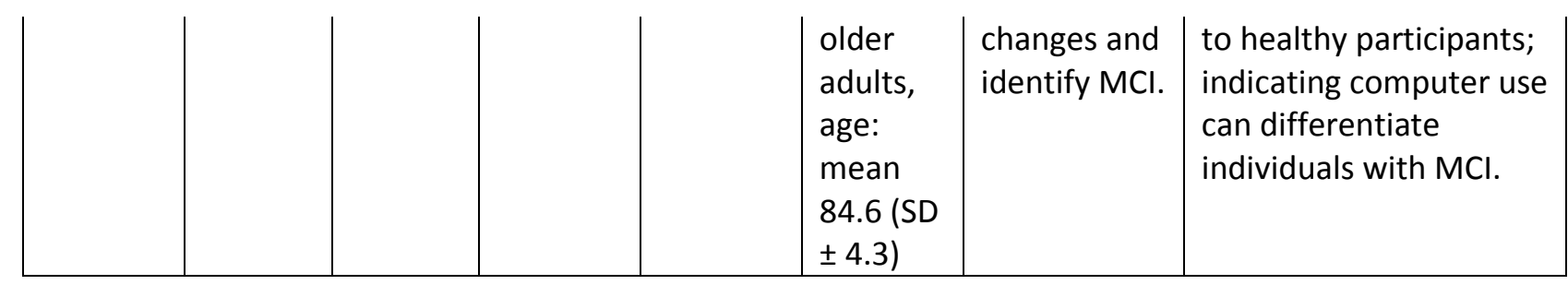

